\title{
EDITORIAL $n^{\circ} 1 / 2018$
}

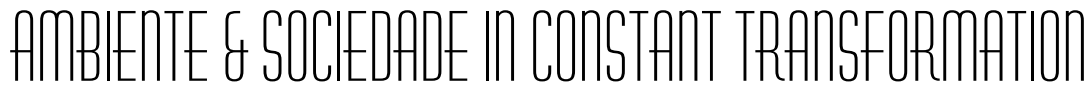

The aim of the first editorial of 2018 is to show the readers all the work that has been done in the journal throughout its 21 years of existence. Ambiente \& Sociedade is an interdisciplinary scientific publication, which contributes to the field of knowledge that spawns between applied social sciences and environmental sciences. Our mission is to add to the construction of scientific and academic knowledge, as well as enhancing this knowledge's visibility by means of original articles with sound research methodology.

Ambiente \& Sociedade's editorial policy seeks to present work that elaborates and discusses the interrelations among social, cultural, and economic dynamics and environmental matters-which endows it with an interdisciplinary approach, by publishing articles about a variety of subjects, such as: environmental health, geography, environmental management, sociology, public policies, environmental education, engineering, political science, architecture, amongst others.

Our main objective is to increase the exposure of Brazilian and Latin-American academic production within a context of an international audience and the primacy of English language, by publishing scientific work made in collaboration by national and international authors, and peer-reviewed by ad-hoc referees.

In the last years the journal has become a regional benchmark by aggregating through ANPPAS a multiplicity of researchers dealing with the trans-sectorial concerns related to the environment. The growing demand that the journal has observed brings the need to count on adjoint, executive, associate, and assistant editors, which Ambiente $\&$ Sociedade could not work without. Today, around 60 people are involved, including tenured and associate professors, renowned researchers and graduate students. This represents an increase of more than 200\% compared with the editorial board of 2013 .

Moreover, maintaining the quality that the journal has acquired over time requires resources necessary for the editorial production: editorial assistance, communication, article proofreading, translation of editorial and promotional material, formatting, and, more recently, converting data to XML format, according to Scielo criteria. In order to keep all these services running, the journal relies on financial resources coming from the submission fees and eventual editorial aid from public notices.

Regarding operational concerns, since 2013, the editors have committed themselves to creating protocols and standardizing evaluation practices, increasing control throughout the whole submission process, as well as ensuring the safety and quality of the evaluation.

Therefore, every submitted manuscript goes through four evaluation stages: 1) the initial screening, when assistant editors check the manuscript and confirm it meets the 
rules and instructions to the authors available on the journal's website; 2) a pre-analysis or desk-review, when the article approved in the previous stage goes through the sieve of the editor-in-chief, adjoint and executive editors to proceed with the evaluation process. In this stage, manuscripts are reviewed to assess pertinence with the journal's scope, quality of research, strong bibliographical review and methodological structuring, contribution to the advancement of knowledge, and interdisciplinary discussion; 3) evaluation, the stage in which the article is refered to an associate editor, a specialist in the field of study who will follow up the peer-review evaluation process; and finally, 4) editorial decision, in which the manuscript, already evaluated by a pair of referees, receives a recommendation by its associate editor and a subsecuent final decision by the editor-in-chief.

However, the inclusion of the journal in the Scielo ScholarOne submission and evaluation system in 2015 had a strong positive impact on the editors' working routine, since, given its well-designed information system and suited to the journal's demands, it increased control, agility, trustfulness, and quality in the analysis processes.

These improvements got Ambiente \& Sociedade many important achievements, such as: indexing in 10 databases like Scielo, Scopus, IBSS, Latindex, Redalyc, amongst others; A1 and A2 scores in eight categories of the last CAPES Web Qualis analysis, increasing the international reach through bilingual publishing, increasing the number of articles written by internacional researchers, incorporating professors of foreing universities; increase of bibliometric indicators such as impact factor and citation number; and finally, a greater audience by adopting a new and modern visual identity and expanding digital advertising in social networks and scientific research websites. This has not only helped to increase the visibility of already published and new articles, but to attract more and more researchers to submit their work to the journal as well.

Translating this into hard data, from 2015 to the first semester of 2018, Ambiente $\&$ Sociedade has received around 800 submissions for analysis, and has approved more than 90 articles and reviews for publication. Currently, our main challenge is to speed up the mean evaluation time through the whole chain of analysis, whilst continuing to guarantee the quality of final editorial decisions, no matter whether it is approval or rejection.

One of the first measures has been the transformation, since the beginning of this year, in relation to the article publication flux. The journal, which used to publish in a quarterly fashion has started to publish in 2018 in a rolling basis, consisting in a single annual volume divided into sections.

This new format has been adopted by many scientific journals. Its main advantage is the higher quickness of the publishing process after the acceptance of the received manuscripts, which sometimes had to wait for the publishing of its corresponding volume. The editors believe this format will benefit both authors and readers, whilst helping enlarge the Journal's audience.

Therefore, as from 2018, the Ambiente \& Sociedade page will be divided as follows: 1) Editorial (reserved for the Journal's editorials by the Editor-in-Chief and Adjoint Editors); 2) Original Articles (containing all the accepted articles corresponding to the current volume/year); 3) Spotlight Issues (this is our former "special issue" section. It is the place for the accepted articles corresponding to our annual special calls - The 2018 
topic is Health and Sustainable Development); 4) Themes in Debate (with articles from renowned researchers, invited by the Editor-in-Chief); and 5) Reviews (dedicated to critical reviews and revisions of books and other academic work).

It is time for change and transformations; we would like to thank all those who already collaborated with our journal over its lifetime, and we invite all of you to enjoy your reading in 2018.

Opening up the new annual volume, the article Repercussions of environmental transformations produced by hydroelectric power plant construction for the health of local families, by authors Lisiane da Rosa, Maria Assunta Busato, Lucimare Ferraz and Silviamar Camponogara seeks to identify, by means of a qualitative study, the health repercussions arising from the implementation of the Foz do Chapecó Hydroelectric Plant, from the point of view of the affected farmer families.

Authors Delcio Pereira, Sieglinde Kindl da Cunha and Liandra Pereira analyzed the cultural and organizational changes in furniture industrial companies since complying to an environmental certification program known as Biomóvel. The study was performed in the Alto Vale do Rio Negro complex (north of Santa Catarina, southern Brasil), using a survey answered by industrial managers, in the article Ecodesign in the furniture industry: opportunities and challenges for organizational insertion.

Authors Karla Rosane do Amaral Demoly and Joceilma Sales Biziu dos Santos analyzed, by means of intervention-research, studied how professors and students envisage environmental education and how these ways of perception transform themselves into workshops designed in a scholar atmosphere. The article is called: Learning, environmental education and school: ways of em-acting in the experience of students and teachers.

Aiming to explore environmental governance through the lens of institutional theory, the authors Tomás de Oliveira Bredariol and Alexandre Louis de Almeida d'Avignon take a study case as starting point to analyze environmental governance of licencing of off-shore oil and gas explotation and production ventures, in the article called Institutions and environmental governance: the case of environmental peritting for offshore oil and gas projects.

The authors Carmen Amelia Trujillo, José Alí Moncada Rangel, Jesús Ramón Aranguren Carrera and Kennedy Rolando Lomas Tapia highlight traditional knowledge associated with water, revealing the meanings of this resource so important to indigenous communities, through qualitative ethnographic research, in the article Meanings of water for the Fakcha Llakta indigenous community of Otavalo, Ecuador.

In the article Floods and social vulnerability: study on the Xingu river in Altamira/PA, Vânia dos Santos Franco, Everaldo Barreiros de Souza and Aline Maria Meiguins de Lima classify social vulnerability in Altamira-PA, considering the ocurrence of seasonal floods and the future scenario of water level stabilization, using the socioenvironmental vulnerability index as their tool.

By means of an interdisciplinary analysis, the article Environmental management in Hotels: sustainable technologies and practices applied in hotels, evaluates hotel environmental management by incorporating sustainable technology and practices con- 
sidering the level of demand by their guests regarding socioenvironmental responsibility and the environmental managament work in hotels with a sustainability index. The authors are Iuri Tavares Amazonas, Rodrigo Freire de Carvalho and Silva and Maristela Oliveira de Andrade.

Authors Deyvison Rhuan Vasco-dos-Santos, Jéssica Vieira dos Santos, Wbaneide Martins de Andrade, Thayse Macedo dos Santos-Lima, Lidiane Nunes Lima, Artur Gomes Dias-Lima, Maria José Gomes de Andrade, Marcos André Vannier dos Santos, Geraldo Jorge Barbosa de Moura and Erika dos Santos Nunes surveyed the use of antiparasitic plants used by the indigenous tribe Kantaruré-Batida and evaluated if the traditional ethno-medical-botanical knowledge is passed down through generations. The article is called Antiparasitic plants used by the Kantaruré-batida indigenous community (NE-Brazil): Ethnobotany and local knowledge-erosion risks.

Aspiring to evaluate legal and technical concordance in mining environmental licencing processes in southern Minas Gerais, authors Leonardo da Silva Junior, Maria Inês Nogueira Alvarenga and Sâmia Regina Garcia Calheiros check whether environmental reports match the reference terms and attendance to the legal requirementes relative to the environmental control reports, in the article called Quality evaluation on environmental licensign processes of minin enterprises in Minas Gerais.

The article Rural women and violence: readings of a reality that approaches fiction, by André Luis Machado Bueno and Marta Julia Marques Lopes, is an epidemiological study about violence against rural women, where it is discussed how social inequalities limit or even hinder full citizenship exercise, therefore becoming a vulnerability factor for countryside women.

In order to evaluate the factors that affect the environmental valuation of urban forest fragments in Manaus (AM - Brazil), authors Henrique dos Santos Pereira, Stephany Anry Kudo and Suzy Cristina Pedroza da Silva surveyed, by means of the pile sorting technique, distinguishing the ecocentric from the antropocentric dwellers' values, in the article called Topophilia and environmental valuation of urban forest fragments in an Amazonian City.

Finally, authors Rafael Junqueira Buralli, Tiago Canelas, Laura Martins de Carvalho, Etienne Duim, Renata Fortes Itagyba, Marília Fonseca, Sofia Lizarralde Oliver and Núria Sanchez Clemente reflect upon the seven Sustainable Development Goals based on the experience of graduate students in the School of Public Health of the University of São Paulo, in the article: Moving Toward the sustainable development goals: the unleash innovation lab experience.

We wish you all an excellent reading.

\section{Pedro Roberto Jacobi}

Editor-in-Chief, Ambiente \& Sociedade Journal

Professor, Education School, University of São Paulo

Professor, Graduate Program in Environmental Science, University of São Paulo 


\section{Leandro Giatti}

Adjoint Editor, Ambiente \& Sociedade Journal

Associate professor, Environmental Health Department, Public Health Faculty, University of São Paulo.

\section{Amanda Martins Jacob}

Editorial Assistant, Ambiente \& Sociedade Journal

MSc, Environmental Science. Graduate Studies Program in Environmental Science, University of São Paulo.

\section{References}

Ambiente \& Sociedade. Sobre nós. São Paulo: ANPPAS, 2018. Disponível em: <http:// www.scielo.br/revistas/asoc/paboutj.htm >.Acesso em 13 de Agosto de 2018.

Ambiente \& Sociedade. Corpo Editorial. São Paulo: ANPPAS, 2018. Disponível em: $<$ http://www.scielo.br/revistas/asoc/pedboard.htm>.Acesso em 13 de Agosto de 2018.

Blog Scielo em Perspectiva Humanas. Ambiente \& Sociedade em constante renovação. São Paulo: Scielo, 2018. Disponível em: http://humanas.blog.scielo.org/blog/2018/08/31/ ambiente-sociedade-em-constante-renovacao/?fbclid=IwAR21GKoOKAPDpowmXG R0tCuasOb8oduHzInyO0XERzFwk2NUNaeNZwMQ_5Y. Acesso em 12 de Setembro de 2018.

Blog Scielo em Perspectiva Humanas. Ambiente \& Sociedade completa 20 anos e participa de Semana Especial no Blog Scielo em Perspectiva Humanas. São Paulo: Scielo, 2018. Disponível em: http:/humanas.blog.scielo.org/blog/2018/08/27/ambiente-sociedade-completa-20-anos-e-participa-de-semana-especial-no-blog-scielo-em-perspectiva-humanas/. Acesso em 12 de Setembro de 2018.

Blog Scielo em Perspectiva Humanas. Ambiente \& Sociedade por dentro: assim funciona o periódico líder na temática socioambiental no Brasil. São Paulo: Scielo, 2018. Disponível em: http://humanas.blog.scielo.org/blog/2018/08/30/ambiente-sociedade-por-dentro-assim-funciona-o-periodico-lider-na-tematica-socioambiental-no-brasil/. Acesso em 12 de Setembro de 2018.

http://dx.doi.org/10.1590/1809-4422asoceditorialvu2018L1

2018;21:e00001

Editorial 
